Bansal Shweta,

$\mathrm{PhD}$ in Economics, Associate Prof. ORCID: 0000-0003-4017-2723

Bansal Vakul, Principal \& Professor, J.V., Jain College (Affiliated to C.C.S. University, Meerut),

ORCID: 0000-0003-0005-6883

\title{
MONETARY POLICY COMPOSITION \& ELEMENTS: A COMPARATIVE STUDY BETWEEN DEVELOPING AND DEVELOPED ECONOMIES
}

Every nation's economy based on the monetary structure. A sound Monetary structure implies the better economic growth for the country, so for being competent economy in the world every nation's tries to adopt better Monetary decisions which are helpful in cyclic development and maintains inflationary pressure, resulting in effective growth in Gross Domestic Product, which refers to the Monetary value in terms of finished goods and services produced with in a country's border in a period of time. In achieving targeted economic growth rate, Monetary Policies plays an important role, how monetary policies maintains stabilized economy growth rate for the country and prevents the downfall in the economy, how assets price and general economic conditions are being affected by a result of monetary policies decisions in the economy, and last but not the least how Monetary Policies committees are being formed? To get the answers of these questions the concept of Monetary Policies composition and its element should be studied. This paper analyses the monetary policies composition, monetary policies Committees set up in different countries for taking monetary decisions Transmission its regulations in different countries that adopted for making sound economy of the country. RBI Monetary Policies reports are taken for the analysis and its transmission analyzed by reviewing the different Committees in developed or developing economies.

Keywords: Monetary Policies Committees, Monetary Policies Framework, Transmission Mechanism, Cyclic Development, Inflationary Pressure, GDP.

Бансал Швета, Бансал Вакул. Склад та елементи грошово-кредитної політики: порівняльне дослідження економік, що розвиваються та розвинених економік.

Економіка кожної краӥни базується на грошово-кредитній системі. Міџна грошово-кредитна система передбачає економічне зростання для країни, тому 
для того, щуоб бути конкурентоспроможною економікою у світі, кожна краӥна намагається приймати кращі рішення в галузі грошово-кредитної політики, які сприяють циклічному розвитку та підтримують інфляційний тиск, щуо призводить до зростання валового внутрішнього продукту, який є ринковою вартістю товарів та послуг, вироблених усередині крайни за певний період часу. Грошово-кредитна політика відіграє важливу роль у досягненні иільових темпів економічного зростання. Дослідження концепиії грошово-кредитної політики та ї̈ елементів дає можливість проаналізувати яким чином грошово-кредитна політика підтримує темпи зростання економіки країни та запобігає падінню економіки, як впливають на ціну активів та загальні економічні умови рішення в галузі грочово-кредитної політики $і$ останнє, але не менш важливе, як формуються Комітети з питань грошово-кредитної політики. У изьому дослідженні проаналізовано структуру грошово-кредитної політики, комітети з монетарної політики, створені в різних краӥнах для прийняття монетарних рішень. Проаналізовано звіти RBI з грошово-кредитної політики та досліджено діяльність Комітетів з питань грошово-кредитної політики розвинених економік та економік краӥн, щзо розвиваються.

Ключові слова: Комітети з питань грошово-кредитної політики, основа грошово-кредитної політики, трансмісійний механізм, циклічний розвиток, інфляційний тиск, ВВП.

\section{INTRODUCTION}

In the developing phase of every economy in the world, every country wants to achieve its best rank in GDP rankings among other countries, for achieving this goal a nation has to become so sound in financial structure of the country, which is depends on the quick and smooth flow between aggregate demand and aggregate supply, better the flow between these two financial structure and economic condition have more strength. for targeting this and maintaining good liquidity Monetary policy should be very primitive in action, to grasp opportunities and strength full enough to build wall for threats to the economy like financial crises downfall in currency rates.

Monetary Policies includes rules and action which are adopted in different situation by Central Bank. the primary objective of the monetary policies to maintain price stability but beside this monetary policy encompasses to achieve different objectives associated with its primary objectives like Unemployment, financial stability at Domestic level or settlements in foreign payment operations. The quantity of individuals varies country wise who choose for framing monetary policies nations. At one side, decisions are made by a single Authority. where the Governor alone is in charge of financial strategy incorporate the Bank of Israel and the Reserve Bank of New Zealand. At the other extraordinary, Central banks work substantial for Monetary strategy (MPCs) that involve in excess of twelve individuals 
A protrusive example is the Governing Council of the European Central Bank which consists of 21 voting members. Similarly, in the U.S. Federal Open Market Committee, 19 members are participating in policy discussions, out of which 12 hold voting rights. Fry, Julius, Mahadeva, Roger, and Sterne (2000) report that 8 (of 82 surveyed) central banks have monetary policy boards with more than 10 members. These changes are made through powerful exchange along a few edges between various household short-term and long-term securities in domestic or in foreign market. For this a sound economy needs strong institutional environment so that loans and advances, exchanges rates in financial market strikes an optimum balance between these by financial market intermediation in domestic and foreign contracts.

\section{REVIEW OF LITERATURE}

The literature on the MPC is young however already spectacular in terms of sheer breadth. what's fascinating is that the wide span of country responses that it's thrown up, making generalization nearly not possible. A non-intrusive, grouping approach would maybe be best suited to drawing lessons from this rich array. The key problems that have attracted interest within the literature are: is that the monetary policy decision-making entity separated out of the central bank's higher-up and government management structure? is this entity individualistic or collegial? what's the look of an entity chargeable for monetary policy formulation and implementation?

Prachi Mishra, Peter Montiel, Rajeswari Sengupta Indira analyzed Monetary Transmission in Developing Countries: Evidence from India (2016)

Cross-country variations within the effectiveness of monetary transmission are doubtless to be necessary. As is well understood, the channels through which monetary policy affects aggregate demand depends on a country's financial structure. Relevant factors embody the extent of the country's links with external money markets, its rate of exchange regime, the dimensions and composition of its formal financial sector, the degree of development of its cash, bond, and stock markets, the liquidity of its markets for real assets such as housing, and both the costs to its banks of doing business as well because the competitive atmosphere in its banking sector. These characteristics differ significantly among countries.

It is examined that broad cross-country differences in the links between central bank policy actions and bank lending rates in advanced, emerging, and low-income economies (LICs). We focus on the association between central bank policy rates and money market rates, as well as that between money market rates and bank lending rates. In doing thus, we tend to seek to unearth suggestive empirical regularities, instead of to spot specific causative relationships. We find a much weaker link between the policy instrument (central bank interest rates) and money market rates in poorer economies than for advanced and emerging economies, both in the short and in the long run. We find a similar result for the link between money market rates and bank lending rates in the short term, and while differences in long-term effects are not as pronounced, they remain weaker in low-income countries. Most importantly, 
changes in money-market rates explain a much smaller proportion of the variance in bank lending rates in low-income countries than in either advanced or emerging economies.

Michael Debabrata Patra and Amaresh Samantaraya discussed on Monetary Policy Committee: What Works and Where (2007)

For working like an independent central bank, needs to restrict the all activities or affiliations by external members outside the central bank operations, these restrictions can be to the financial institution, political influence and government policies. While in other case, it is seen in some countries, restricts or prevents the activities of those financial institutions which is come as financial difficulties to the Central bank, that's why central banks need to restricts the activities of member to be not engaged in other financial institutional outside the central bank.

There is gradualist change can be seen in India in context of the monetary policy framework, RBI constitutes the TAC in Monetary Policies Committees which was set up not for the taking response to shocks or loss of credibility but it is set up for something more evolutionary, it is open interactive approach to the monetary policy and launched in the late 1990s and intensified from mid-2003, after that, many reforms has been taken place and all decisions taken with centralized system in accordance with RBI Governor.

Thórarinn G. Pétursson has studied the transmission of monetary policy through the financial system (2001)

The first stage of the mechanism is that the economic system channel. There, monetary policy actions are primarily manifested by changes briefly and long-term interest rates, quality costs, liquidity and also the rate of exchange of domestic currency. An amendment within the financial organization policy rate has an instantaneous impact within the securities industry (the marketplace for securities with maturity from one day to at least one year). A rise within the policy rate usually results in an on the spot rise in interbank and T-bill rates, though not essentially by an equivalent amount; this relies among different things on the securities' maturity compared thereupon of the instrument priced by the policy rate, and the way actively the instrument in question is listed. Interest rates on commercial banks' short-run instruments ought to rise comparatively quickly, since they're commonly supported to a large extent within the money markets. Interest rates on short term variable-rate loans rise before long after. Rates on short-term fixed-rate instruments also rise, but in general after some lag. Monetary policy usually doesn't have a lot of impact on the unfold between disposition and borrowing rates, therefore deposit rates ought to additionally rise fairly before long once an increase within the policy rate.

\section{NEED OF THE STUDY}

By reviewing different literature, it is found there are several studies has been done on the transmission channels of monetary policy, Interest rates influences the aggregate demand, output and price and these all macro variables collectively formed 
transmission mechanism of monetary policy and Some studies focused on the monetary policy transmission and its framework, monetary policies rules. But there are no studies which are done in context of Monetary Policy Composition \& Elements: A Comparative study between Developing and Developed countries so the researcher wants to study about it.

\section{OBJECTIVE OF THE STUDY}

To study and find out the comparison of Monetary Policies Composition in selected developed and developing countries.

DATA COLLECTION- Data is secondary, which have collected through various websites, Monetary policy Reports, published by selected countries have also taken in Research.

\section{SAMPLE SIZE \& TECHNIQUES}

Convenient sampling has been used, for comparing the Monetary Composition and elements SAARC group is selected for developing Countries and Developed countries selected on the basis of world bank list 2018. Exploratory approach has followed, comparative analysis done on the basis of composition, elements and events taken between Developed and Developing countries.

\section{DATA ANALYSIS \& INTERPRETATION}

It is observed that composition of MPC is complex and convenient for decision making which includes short term and medium-term forecasts regulated under the central bank. MPC composition is sometimes short and members can be excluded and included according to situation, in Large composition of MPC receives advice by NonVoting members and central bank staff for decision making (Table 1).

MPC - Administrative Structure in Different Countries

Table 1

Source Central Bank websites

\begin{tabular}{|l|l|c|c|c|c|}
\hline Country Name & Name of the Body/ & $\begin{array}{c}\text { Separate } \\
\text { Entity }\end{array}$ & $\begin{array}{c}\text { Decision } \\
\text { making } \\
\text { /Advisory }\end{array}$ & $\begin{array}{c}\text { Reports to } \\
\text { government } \\
\text { legislature }\end{array}$ & $\begin{array}{c}\text { Legal } \\
\text { Mandate }\end{array}$ \\
\hline $\begin{array}{l}\text { Australia } \\
€\end{array}$ & $\begin{array}{l}\text { Reserve Bank } \\
\text { Board }\end{array}$ & No & D & Yes & Yes \\
\hline Brazil & $\begin{array}{l}\text { MPC (known as } \\
\text { COPOM) }\end{array}$ & No & D & Yes & Yes \\
\hline $\begin{array}{l}\text { China } \\
€\end{array}$ & MPC & Yes & A & Yes & Yes \\
\hline $\begin{array}{l}\text { Columbia } \\
¥ \\
€\end{array}$ & Board of Directors & Yes & D & Yes & Yes \\
\hline
\end{tabular}




\begin{tabular}{|l|l|c|c|c|c|}
\hline Country Name & Name of the Body/ & $\begin{array}{c}\text { Separate } \\
\text { Entity }\end{array}$ & $\begin{array}{c}\text { Decision } \\
\text { making } \\
\text { /Advisory }\end{array}$ & $\begin{array}{c}\text { Reports to } \\
\text { government } \\
\text { legislature }\end{array}$ & $\begin{array}{c}\text { Legal } \\
\text { Mandate }\end{array}$ \\
\hline Japan & Policy Board & No & D & Yes & Yes \\
\hline Korea & MPC & Yes & D & Yes & Yes \\
\hline Mexico & Board of Governors & No & D & Yes & Yes \\
\hline $\begin{array}{l}\text { Norway } \\
€\end{array}$ & Executive Board & Yes & D & Yes & Yes \\
\hline Sweden & Executive Board & No & D & Yes & Yes \\
\hline $\begin{array}{l}\text { Canada } \\
€\end{array}$ & Governing Council & No & D & Yes & Yes \\
\hline $\begin{array}{l}\text { India } \\
\text { Technical Advisory }\end{array}$ & Yes & A & No & No \\
\hline $\begin{array}{l}\text { UK } \\
€\end{array}$ & MPC & Yes & D & Yes & Yes \\
\hline
\end{tabular}

$¥:$ Government participation as a voting member.

$£$ : Government membership in non-voting capacity.

$€$ : Government override capacity on MPC decisions.

D: Decision making. A: Advisory.

Structure of the MPC is different according wise to country's Economies, MPC'S structured and its working method is dynamically changing according to the situation. MPC body name in different countries with different name working for the same objective mostly to maintain price stability. In committee's formulation internal and external experts are selected through Experts Review panel by Government. Voting rights are given for taking particular decision then majority of votes favoring one decision should be taken. The MPC have separate legal entity which works according to the Central bank but in some countries Government interference influence the separate entity. In Australia (Reserve Bank Board) And China Government is the member in MPC decisions or can override the MPC decisions. But in case of China MPC is less influence because it acts as Separate legal Entity. Autonomous decision-making method is taken by committee's members not by taking consent of non - voting members Japan have policy board, basic name given to the MPC as it works for policy making, the board have to take decisions under the Government. All countries have legal Mandate for the MPC excluding India in which TAC doesn't have legal mandate nor it report to government Legislature. In Norway (Executive Board) and Korea MPC's work like separate entity and Decision report send to Government legislature, Decision taken self by the MPC. While in Sweden same As Executive Board in Norway but it takes decisions by government, same implies to Canada but there is Government Override capacity on MPC decisions. 


\section{Source:-SBP (State Bank of Pakistan Monetary Report)}

\begin{tabular}{|l|l|c|c|}
\hline \multicolumn{4}{|c|}{ Appointment of the Governor and Tenure in SAARC group } \\
\hline & \multicolumn{1}{|c|}{ Appointing Authority } & $\begin{array}{c}\text { Tenure } \\
\text { in Years }\end{array}$ & Renewability \\
\hline Afghanistan & $\begin{array}{l}\text { On the basis of the } \\
\text { parliament and } \\
\text { recommendations of } \\
\text { President }\end{array}$ & 5 & Two times \\
\hline Bangladesh & $\begin{array}{l}\text { By Prime Minister, list } \\
\text { of nominees selected } \\
\text { by Ministry of Finance }\end{array}$ & 4 & Unlimited, till age of 65 years \\
\hline Bhutan & $\begin{array}{l}\text { By majesty King, with } \\
\text { Recommendations of } \\
\text { the Prime Minister }\end{array}$ & 5 & One Terms \\
\hline India & Central Government & 5 & Unlimited terms \\
\hline Maldives & $\begin{array}{l}\text { By the Parliament, } \\
\text { recommendations of } \\
\text { the President }\end{array}$ & 7 & $\begin{array}{c}\text { Two Terms with consent of } \\
\text { President and the Parliament }\end{array}$ \\
\hline Nepal & Central Government & 5 & One time \\
\hline Pakistan & President & 3 & Two times till age of 65 years \\
\hline Sri lanka & $\begin{array}{l}\text { recommendations of } \\
\text { the President by } \\
\text { Ministry of Finance }\end{array}$ & 6 & Unlimited terms \\
\hline
\end{tabular}

The Governor, Deputy Governors and other Directors are appointed by Government of Nepal, Council of Ministers for term of five years. reappoint the retiring Governor for another one term and the retiring other Directors for any term, if it is deemed necessary The Board of Directors is a rulemaking authority consisting of seven people: a royally appointed Governor, as chair; two Deputy Governors, one of whom serves as Secretary; and four others appointed by the government including one member of the Ministry of Finance. The appointed members hold office for five years, may be reappointed once, and are forbidden to hold political affiliations or substantial interests - including any shares - in financial institutions. In Afghanistan Central bank Governor is chosen on the basis of parliament and with recommendation of Government who have the tenure of 5 years and selected twice. Maldives have the highest period of tenure for governor is 7 Years who is selected by both government and president Recommendation and selected Twice Sri Lanka and India have renewal period for Central Bank Governor unlimited times

\section{CONCLUDING OBSERVATIONS}

Apart from achieving better macroeconomic outcomes, it is sometimes argued that group decision making has another important advantage over individual decision 
making: it is found in the MCPc's structure on different factors The Bank of England and the Bank of Japan are often held up as examples: Both became vastly more open when they adopted formal monetary policy committee structures. But the BoJ is still not a leader in terms of transparency, whereas «one-man shows» such as the Reserve Bank of New Zealand are. Similarly, the group decision making processes at the FOMC and the ECBs Governing Council are far from models of transparency.

Committee may not diversify the nation's monetary policy portfolio much more than a Single decision maker would. So, the very same lines of reasoning that favor committees over individuals appear to favor genuinely-collegial or individualistic committees over autocratically-collegial ones. At this point, you may be wondering: Didn't Alan Greenspan do a pretty superb job of leading the FOMC For India, at the current juncture, the choice is a separate TAC; advisory; collegial; large by international standards; more external members than internal; restrictions on public issuances by members around policy review announcements; quarterly meetings; voting without publication; continuity with change. I proceeded through the catalogue of reasons to prefer a monetary policy committee to a single individual, most of the reasons also pointed to an individualistic committee structure, rather than to a collegial one, Except for one, a Monetary policy committee that is too egalitarian runs the aforementioned danger of speaking with too many voices. If the result is a cacophony rather than clarity, that may confuse rather than enlighten the markets and the public thereby turning transparency into noise. And that, in turn, can hamper the operation of monetary policy.

\section{REFERENCES}

1. https://www.nrb.org.np/aboutus/bod.php

2. https://www.ideasforindia.in/topics/macroeconomics/monetary-policy-in-indiaand-other-developing-countries.html

3. https://en.wikipedia.org/wiki/Constitution_of_Bhutan

4. https://en.wikipedia.org/wiki/Royal_Monetary_Authority_of_Bhutan 